\title{
First cases of contagious ovine digital dermatitis in Germany
}

\author{
Philip Christian Tegtmeyer ${ }^{1 \dagger}$, Gareth James Staton ${ }^{2 \dagger}$, Nicholas James Evans ${ }^{2}$, Judith Rohde ${ }^{3}$, \\ Teresa Maria Punsmann ${ }^{1}$ and Martin Ganter ${ }^{1^{*}}$ (D)
}

\begin{abstract}
Contagious ovine digital dermatitis (CODD) is a significant disease of the ovine foot characterised by severe lameness and progressive separation of the hoof horn capsule from the underlying tissue. Similar to bovine digital dermatitis (BDD), pathogenic members of the genus Treponema including the Treponema medium phylogroup, Treponema phagedenis phylogroup and Treponema pedis are frequently found together in CODD lesions. To date, CODD was only described in Ireland and the United Kingdom. In northern Germany, cases of an unusually severe lameness presented in a sheep flock that had been affected by footrot for several years. These cases were non-responsive to conventional footrot therapies, with some sheep exhibiting substantial lesions of the claw horn that resulted in horn detachment. Lesion swab samples were collected from both clinically affected and asymptomatic animals. In all clinically affected sheep, CODD-associated Treponema phylogroups were detected by polymerase chain reaction. This is the first report of CODD in Germany and mainland Europe, indicating a wider geographic spread than previously considered. In cases of severe lameness attributed to claw lesions in sheep that fail to respond to footrot treatment, CODD should be considered irrespective of geographic location.
\end{abstract}

Keywords: Footrot, Lameness, Sheep, Treponema

\section{Background}

A novel disease of sheep claws, termed contagious ovine digital dermatitis (CODD), was first described in the UK in 1997 [1]. The disease is characterised by severe lameness associated with initial inflammation of the coronary band. The disease usually begins with an infection of the claw horn at the coronet, which underruns the hoof horn capsule abaxially. Subsequently, there is a progressive separation of the claw from the underlying tissue. In severe cases, the entire claw horn may be avulsed, leaving the sensitive lamellae exposed [1-5]. The consequences

\footnotetext{
*Correspondence: martin.ganter@tiho-hannover.de

†Philip Christian Tegtmeyer and Gareth James Staton contributed equally to this work

${ }^{1}$ Clinic for Swine, Small Ruminants and Forensic Medicine, University of Veterinary Medicine Hannover, Foundation, Bischofsholer Damm 15, 30173 Hannover, Germany

Full list of author information is available at the end of the article
}

of the severe lameness include poor body condition and frequent recumbency $[1,4,6]$. In sheep, other causes of infectious lameness, including footrot and interdigital dermatitis, are frequently diagnosed. Ovine footrot, is considered to be caused by Dichelobacter nodosus and Fusobacterium necrophorum, and is strongly associated with CODD [7]. However, despite the detection of $D$. nodosus and $F$. necrophorum in CODD $[2,8]$, the disease is regarded as distinct from footrot or the associated condition, ovine interdigital dermatitis [9]. Whilst considered multifactorial and polymicrobial, there is substantial evidence that the major aetiological agents of CODD are Treponema spp., with implicated phylogroups identical to those involved in bovine digital dermatitis (BDD): Treponema medium phylogroup, Treponema phagedenis phylogroup and Treponema pedis [10-16]. Other Treponema -associated diseases with distinct clinical 
presentations have also been identified in goats [17-19] and wild elk [20].

CODD is now common across the United Kingdom. The proportion of farms affected by CODD ranges from $53 \%$ in England, with an intra-flock prevalence of 2.4\% [21], to $35.0 \%$ in Wales, with median on farm prevalence of $2.0 \%$ [22]. In a recent follow-up survey of 1260 farmers in England, $48.7 \%$ of respondents reported CODD on their farms with a mean farm prevalence of $2.3 \%$ [23]. Until now, CODD has only been reported in the United Kingdom and Ireland, but it is likely that the disease has spread beyond these boundaries [24]. This report describes the first known outbreak of CODD in Germany and mainland Europe.

\section{Case presentation}

In 2016 a flock of $\sim 850$ ewes were moved to new dykes at the mouth of the river Elbe in Lower Saxony, district of Cuxhaven, Germany. The area had recently been grazed by another sheep flock with unknown footrot status. The flock under investigation had a history of footrot and the recent flock movement resulted in increased prevalence. This largely closed flock had only had three breeding rams purchased between 2015 and 2018. One ram was purchased from a mixed farm that bred both sheep and cattle whilst the other two were from sheep farms. The footrot status of these three farms and the BDD status of the mixed farm were unknown. Heavy rainfall with warm and humid conditions in the area were recorded in the summer/autumn of 2017, which was a challenge to sheep farming generally. In the flock described, the number of lame sheep increased during this period. Due to persistent wet weather, the whole flock was housed 7 weeks earlier than usual (1st November 2017) in a new-built barn instead of typical transfer to housing at the end of December (prior to lambing).

In December 2017, a local veterinary surgeon asked for advice concerning treatment of 200 lame sheep with severe footrot. The farmer had treated the sheep by claw trimming, footbaths (zinc sulphate) and a topical oxytetracycline spray (Animedazon ${ }^{\circledR}$, Livisto, Senden-Bösensell, Germany), which was the classical footrot treatment [25], but was still unable to stop the spread of lameness in the flock. Since footrot was suspected, advice was given to stop footbathing and to administer gamithromycin $\left(\right.$ Zactran $^{\circledR}$, Boehringer Ingelheim Vetmedica $\mathrm{GmbH}$, Ingelheim, Germany) or tulathromycin (Draxxin $100 \mathrm{mg} /$ $\mathrm{ml}{ }^{\circledR}$, Zoetis Deutschland GmbH, Berlin, Germany) by injection to all lame sheep. The veterinarian was also advised to avoid claw trimming; claws were therefore only clipped if excessively long, but not earlier than five to 10 days after systemic antibiotic treatment.
About 150 of the severely lame sheep were treated in the first week of January 2018 with gamithromycin. The systemic antibiotic treatment was successful in treating symptomatic individuals within the flock during the housing period, although further asymptomatic, untreated sheep continued to become lame.

On January 15, 2018, the farmer brought two severely lame (locomotion score 5 of 6 ) sheep suffering from claw inflammation to the University of Veterinary Medicine Hannover. The animals were hospitalized for further examinations, diagnosis and treatment. On January 31, 2018, the farm was visited for clinical examination and sampling of lame sheep.

The two hospitalized sheep exhibited severe hoof horn defects, beginning at the proximal coronary band. In both sheep, complete detachment of the hoof horn capsule was observed, which for sheep 1 was present in both claws from the same leg (Fig. 1a) whilst in sheep 2 only one claw was affected (Fig. 1b).

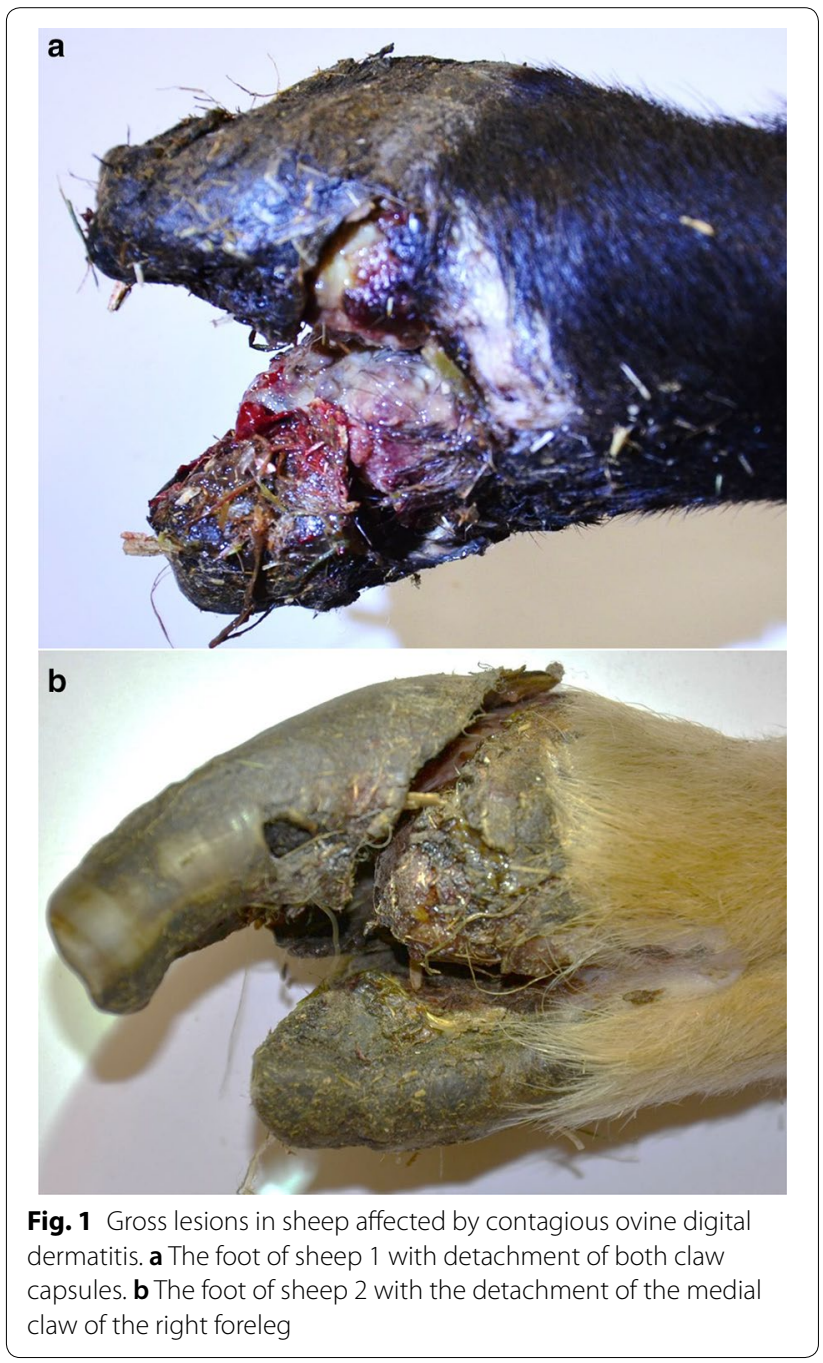


The sheep at the farm were housed with less than one $\mathrm{m}^{2}$ per sheep, therefore individual lameness scoring was not possible. The lambs, with a maximum age of 36 days, were not yet affected at that time. Clinical examination of 10 pre-selected lame, untreated sheep revealed severe claw lesions. The loss of horn at the proximal coronary band was prevalent in these animals. During the visit no more newly lame and untreated sheep were found. Details of the clinical findings in the 12 sheep were documented according to a recognised scheme [26] and are listed in additional file 1.

Additionally, biopsies of the coronary band were taken and stored in liquid nitrogen from 11 affected sheep on farm and 10 asymptomatic control sheep from the healthy flock of the Clinic. Tissue samples were taken by skin biopsy stamp (Biopsie Punch Hautstanzen, $3 \mathrm{~mm}$, WDT Curavet, Garbsen, Germany) at the boundary of claw and coronary band and crossed the border between affected/non-affected tissues. Biopsies were taken under local anaesthesia by injecting $1 \mathrm{~mL}$ of Procaine- $\mathrm{HCl}$ locally subcutaneously (Isocain, Selectavet,Weyarn, Germany) and stored in liquid nitrogen immediately after sampling.

From the two symptomatic, hospitalized sheep, swabs from the interdigital space and coronary band were Gram-stained and microscopically surveyed for spirochaetes. From the 10 pre-selected lame sheep on farm, interdigital swabs were taken for bacterial culture to detect $D$. nodosus. Pus and necrotic material from underneath lost hoof horn and from the brim of infected tissue were collected with bacterial plastic loops and inoculated onto Eugon agar containing $0.2 \%$ yeast extract and $10 \%$ horse blood with and without $1 \mu \mathrm{g} / \mathrm{mL}$ lincomycin [27]. On farm, streaked culture plates were immediately placed into anaerobic jars with anaerobic gas generating sachets and, in the laboratory of the Institute for Microbiology, incubated at $37{ }^{\circ} \mathrm{C}$ for 6 days. Bacteria with characteristic colony morphology were tested using Polymerase Chain Reaction (PCR) [28].

Swabs from the interdigital space and from lesions at the coronary band of the affected feet of the 12 sheep were investigated for D. nodosus by PCR [29].

Frozen samples were sent on dry ice to the Department of Infection Biology \& Microbiomes, University of Liverpool, United Kingdom, for a molecular genetic examination focussed on Treponema spp.. One affected animal with chronic lesions and detachment of hoof horn was not tested for treponemes due to the late stage of the disease. Upon receipt, tissues from lesions and healthy controls were thawed and DNA extracted using a DNeasy Kit (Qiagen, United Kingdom) in accordance with the manufacturer's instructions. Extracted DNA was stored at $-20{ }^{\circ} \mathrm{C}$ until analysis. Samples were subjected to a Treponema genus PCR, capable of detecting both pathogenic and commensal Treponema spp., as described previously [30]. Samples were additionally subjected to nested PCR assays specific for the three BDD-associated treponeme groups ( $T$. medium phylogroup, $T$. phagedenis phylogroup and T. pedis) as described previously [10]. A water control and genomic DNA from each of the three treponeme phylogroups were used as negative and positive controls, respectively.

Eleven of the 12 examined sheep showed coronary band lesions and in 6 of 12, one horn capsule was detached (Additional file 1). Typically, coronary band lesions and exungulations were found in all sheep and involved at least one foot. In addition, typical footrot symptoms with inflammation running from the interdigital space under the axial horn to the sole followed by an inflammation of the abaxial dermis were found in all 12 sheep, with 8 of the 12 having more than one foot affected.

Gram staining of claw swab smears from the symptomatic sheep in the clinic identified spirochaetes on microscopic examination (Table 1). D. nodosus could be isolated and differentiated from 2 of the 10 sheep sampled on farm (Table 1 ). The $D$. nodosus PCR was negative for one hospitalized sheep with an inconclusive result for the second (Table 1). Claw swab samples of the 10 sheep sampled in the flock were positive in seven cases with a further two samples inconclusive.

In all 10 clinically symptomatic samples Treponema spp. PCR and specific PCRs for T. medium phylogoup, T. phagedenis phylogroup and T. pedis were positive (Table 1). One sample from a healthy control sheep was positive for T. medium and T. pedis in the treponeme phylogroup-specific PCR assay also.

\section{Discussion and conclusions}

In the flock described here, the conventional footrot treatments with hoof trimming and footbaths failed. As spirochaete bacteria were initially detected in the two hospitalized cases by Gram-staining of the smears of the interdigital space, diagnosis of CODD was suspected, although footrot was not excluded [31], for D. nodosus was detected by culture and PCR in some of the affected sheep (see Table 1). The diagnosis of CODD was confirmed by identifying specific, pathogenic Treponema phylogroups in all 11 sheep tested by PCR. In all 11 sheep, T. pedis and T. phagedenis phylogroup were present, with T. medium phylogroup identified in 10 of the 11. This is the first published report of CODD in sheep in Germany and in mainland Europe.

As previously reported, the genus-specific Treponema assay is not disease specific [13], and our tests showed positive results for both affected and one healthy animal. This control animal was tested positive for the 
Table 1 Findings in claw swabs or claw biopsies by different bacteriological methods

\begin{tabular}{|c|c|c|c|c|c|c|c|c|c|}
\hline Animal no. & Sampling at & TWDS-Score & $\begin{array}{l}\text { Detection } \\
\text { of Spirochaetes } \\
\text { by Gram stain }\end{array}$ & $\begin{array}{l}\text { D. } \\
\text { nodosus } \\
\text { culture }\end{array}$ & D. nodosus PCR & $\begin{array}{l}\text { Treponema } \\
\text { spp. PCR }\end{array}$ & $\begin{array}{l}\text { T. medium/T. } \\
\text { vincentii-like }\end{array}$ & $\begin{array}{l}\text { T. } \\
\text { phagedenis- } \\
\text { like }\end{array}$ & T. pedis \\
\hline 1 & Clinic & 15 & + & n.d. & - & + & + & + & + \\
\hline 2 & Clinic & 18 & + & n.d. & \pm & + & + & + & + \\
\hline 3 & Farm & 34 & n.d. & - & + & + & + & + & + \\
\hline 4 & Farm & 72 & n.d. & - & + & + & + & + & + \\
\hline 5 & Farm & 102 & n.d. & - & \pm & + & + & + & + \\
\hline 6 & Farm & 52 & n.d. & - & \pm & + & + & + & + \\
\hline 7 & Farm & 36 & n.d. & - & \pm & n.d. & n.d. & n.d. & n.d. \\
\hline 8 & Farm & 40 & n.d. & - & + & + & + & + & + \\
\hline 9 & Farm & 4 & n.d. & - & + & + & + & + & + \\
\hline 10 & Farm & 34 & n.d. & + & + & + & + & + & + \\
\hline 11 & Farm & 136 & n.d. & + & + & + & + & + & + \\
\hline 12 & Farm & 68 & n.d. & - & + & + & - & + & + \\
\hline 13 & Control & 0 & n.d. & n.d. & n.d. & - & - & - & - \\
\hline 14 & Control & 0 & n.d. & n.d. & n.d. & + & + & - & + \\
\hline 15 & Control & 0 & n.d. & n.d. & n.d. & + & - & - & - \\
\hline 16 & Control & 0 & n.d. & n.d. & n.d. & + & - & - & - \\
\hline 17 & Control & 0 & n.d. & n.d. & n.d. & - & - & - & - \\
\hline 18 & Control & 0 & n.d. & n.d. & n.d. & + & - & - & - \\
\hline
\end{tabular}

+, positive; - , negative; \pm , inconclusive; TWDS, Total weighted digital score according to Wittington and Nicholls (1995) [41]; n.d., not determined

CODD specific phylogroups T. medium and T. pedis by PCR. The control sheep are housed in the direct vicinity of pigs, whose gastrointestinal tract can be a source of commensal treponemes as well as Treponema pedis [32, 33]. Up to now (July 2020), none of the control sheep, which are still housed on the same location, have developed lameness.

The flock where CODD occurred had a long history of footrot. The prevalence of lameness in the flock was estimated to be less than $5 \%$ in the summer of 2017 by the farmer. However, due to the endemic situation of $\mathrm{BDD}$ in the cattle herds in that region, there were potentially numerous possibilities for treponemal infections to spread between infected cattle and naive sheep flocks. A ram introduced from a mixed sheep and cattle farm is one possible infection source. Current evidence suggests potential roles for the bovine gastrointestinal tract, slurry, and hoof trimming equipment in the transmission of BDD [33-36]. It is very common in the northern coastal region of Germany for sheep to graze in late autumn and winter on pastures that have been previously used for grazing cattle, or fertilised by slurry. BDD is highly prevalent in the cattle herds in that region [37], and this may represent an important disease transmission route [38]. Introduction of CODD might also have been caused by visitors to the dyke or the farm. Hoof trimming was only performed by the shepherd and his son; mitigating any infection risk posed from professional hoof trimmers [35].

As most sheep flocks in Germany are closed epidemiological units, it should be possible to control the spread of CODD between sheep farms. In general, only breeding rams are purchased, and it is therefore possible that the quarantine of rams could help to avoid introduction of CODD. In Germany, no stratification system exists. The presence of BDD in cattle on farm is a risk factor for CODD [39], suggesting that if sheep are co-grazed there may be transmission of BDD treponemes. Furthermore, given the intestinal tract of catthe is a known reservoir of BDD treponemes [34], there may be a potential infection risk if sheep are grazed on pastures fertilised with cattle slurry. There was presumably direct or indirect contact of the affected flock to dairy cattle with BDD. Whilst sheep were not purchased from other farms, several other reported risk factors including large flock size, adult sheep, time of year and the housing of sheep $[39,40]$ were identified for this flock. These risk factors might have increased the susceptibility of this flock to footrot and CODD. Moreover, the summer and autumn months of 2017 were warm with unusually high rainfall. Even in the winter of $2017 / 18$, pastures were wet and the feet of these sheep were exposed to prolonged wet conditions. The affected animals were housed in the new barn, but 
there were no other means adopted to stop the distribution of infection other than classical footrot treatment. Despite treatment failure, affected animals were not isolated and the barn was not mucked, or disinfected to reduce risk of transmission. Neither the local veterinarian nor the farmer were previously aware of CODD.

In summary we present the first recorded case of CODD in mainland Europe and we encourage continued vigilance and surveillance of CODD both in Europe and worldwide.

\section{Supplementary information}

Supplementary information accompanies this paper at https://doi. org/10.1186/s13028-020-00544-0.

Additional file 1: Clinical findings at the claws with footrot scoring according to Egerton and Roberts (1971) and additional findings. *TWDS = Total weighted digital score according to Whittington und Nicholls [41]. **CODD lesion grade according to Angell et al. [5].

\section{Acknowledgements}

We thank Antje Polifka for performing the D. nodosus PCR in the clinical lab. Many thanks to the local veterinarian and the owner of the sheep.

\section{Prior publication}

Data included in this article has previously been published in the proceedings of the Tagung der DVG-Fachgruppe Krankheiten kleiner Wiederkäuer, Landquart, Switzerland, June 13th-15th 2018.

\section{Authors' contributions}

PCT visited the farm, made the clinical investigations and took the samples there. TP made the clinical examination and the sampling of the animals in the Clinic for Swine, Small Ruminants and Forensic Medicine. NJE advised on CODD testing and supervised treponeme assays whilst GS carried out the molecular assays and completed their interpretation. JR performed the D. nodosus culture. MG coordinated the work and wrote the initial manuscript. PCT, GJS, NJE, TMP, JR, and MG were all involved in the interpretation of results and drawing of conclusions. NJE and GJS made the linguistically proofreading of the manuscript. All authors read and approved the final manuscript.

\section{Funding}

Open access funding provided by Projekt DEAL. The study is financed entirely by institutional funds.

\section{Availability of data and materials}

The datasets used are available from the corresponding author on reasonable request.

\section{Ethics approval and consent to participate}

This case report did not require official or institutional ethical approval. Animals were handled according to high ethical standards and national legislation.

\section{Consent for publication}

Not applicable.

\section{Competing interests}

The authors declare that they have no competing interests.

\section{Author details}

${ }^{1}$ Clinic for Swine, Small Ruminants and Forensic Medicine, University of Veterinary Medicine Hannover, Foundation, Bischofsholer Damm 15, 30173 Hannover, Germany. ${ }^{2}$ Department of Infection Biology and Microbiomes, Institute of Infection, Veterinary and Ecological Sciences, University of Liverpool, Leahurst Campus, Chester High Rd, Neston, Liverpool CH64 7TE, UK. ${ }^{3}$ Institute for Microbiology, University of Veterinary Medicine, Hannover, Foundation, Bischofsholer Damm 15, 30173 Hannover, Germany.

Received: 2 January 2020 Accepted: 20 August 2020

Published online: 27 August 2020

\section{References}

1. Harwood DG, Cattell JH, Lewis CJ, Naylor R. Virulent foot rot in sheep. Vet Rec. 1997;140:687.

2. Naylor RD, Martin PK, Jones JR, Burnell MC. Isolation of spirochaetes from an incident of severe virulent ovine footrot. Vet Rec. 1998;143:690-1.

3. Wassink GJ, Moore LJ, Grogono-Thomas R, Green LE. Exploratory findings on the prevalence of contagious ovine digital dermatitis in sheep in England and Wales during 1999 to 2000. Vet Rec. 2003;152:504-6.

4. Winter AC. Lameness in sheep. Small Rumin Res. 2008;76:149-53.

5. Angell JW, Blundell R, Grove-White DH, Duncan JS. Clinical and radiographic features of contagious ovine digital dermatitis and a novel lesion grading system. Vet Rec. 2015;176:544.

6. Duncan JS, Grove-White D, Moks E, Carroll D, Oultram JW, Phythian CJ, et al. Impact of footrot vaccination and antibiotic therapy on footrot and contagious ovine digital dermatitis. Vet Rec. 2012;170:462.

7. Angell JW, Clegg SR, Grove-White DH, Blowey RH, Carter SD, Duncan JS, et al. Survival of contagious ovine digital dermatitis (CODD)-associated treponemes on disposable gloves after handling CODD affected feet. Vet Rec. 2017;181:89.

8. Moore LJ, Wassink GJ, Green LE, Grogono-Thomas R. The detection and characterisation of Dichelobacter nodosus from cases of ovine footrot in England and Wales. Vet Microbiol. 2005;108:57-67.

9. Wilson-Welder JH, Alt DP, Nally JE. The etiology of digital dermatitis in ruminants: recent perspectives. Vet Med (Auckl). 2015;6:155-64.

10. Evans NJ, Brown JM, Demirkan I, Singh P, Getty B, Timofte D, et al. Association of unique, isolated treponemes with bovine digital dermatitis lesions. J Clin Microbiol. 2009:47:689-96.

11. Klitgaard K, Bretó AF, Boye M, Jensen TK. Targeting the treponemal microbiome of digital dermatitis infections by high-resolution phylogenetic analyses and comparison with fluorescent in situ hybridization. J Clin Microbiol. 2013;51:2212-9.

12. Krull AC, Shearer JK, Gorden PJ, Cooper VL, Phillips GJ, Plummer PJ. Deep sequencing analysis reveals temporal microbiota changes associated with development of bovine digital dermatitis. Infect Immun. 2014;82:3359-73.

13. Sullivan LE, Clegg SR, Angell JW, Newbrook K, Blowey RW, Carter D, et al. The high association of bovine digital dermatitis Treponema spp. with contagious ovine digital dermatitis lesions and the presence of Fusobacterium necrophorum and Dichelobacter nodosus. J Clin Microbiol. 2015;53:1628-38.

14. Nielsen MW, Strube ML, Isbrand A, Al-Medrasi WD, Boye M, Jensen TK, et al. Potential bacterial core species associated with digital dermatitis in cattle herds identified by molecular profiling of interdigital skin samples. Vet Microbiol. 2016;186:139-49.

15. Santos TM, Pereira RV, Caixeta LS, Guard CL, Bicalho RC. Microbial diversity in bovine papillomatous digital dermatitis in Holstein dairy cows from upstate New York. FEMS Microbiol Ecol. 2012;79:518-29.

16. Zinicola M, Higgins H, Lima S, Machado V, Guard C, Bicalho R. Shotgun metagenomics sequencing reveals functional genes and microbiome associated with bovine digital dermatitis. PLoS ONE. 2015;10:e0133674.

17. Sullivan LE, Evans NJ, Clegg SR, Carter SD, Horsfield JE, Grove-White D, et al. Digital dermatitis treponemes associated with a severe foot disease in dairy goats. Vet Rec. 2015;176:283. https://doi.org/10.1136/vr.102858.

18. Groenevelt M, Anzuino K, Langton DA, Grogono-Thomas R. Association of treponeme species with atypical foot lesions in goats. Vet Rec. 2015;176:626

19. Groenevelt M, Anzuino K, Smith S, Lee MR, Grogono-Thomas R. A case report of lameness in two dairy goat herds; a suspected combination of nutritional factors concurrent with treponeme infection. BMC Res Notes. 2015:8:791.

20. Clegg SR, Mansfield KG, Newbrook K, Sullivan LE, Blowey RW, Carter SD, et al. Isolation of digital dermatitis treponemes from hoof lesions in wild 
North American elk (Cervus elaphus) in Washington State, USA. J Clin Microbiol. 2014;53:88-94.

21. Kaler J, Green LE. Naming and recognition of six foot lesions of sheep using written and pictorial information: a study of 809 English sheep farmers. Prev Vet Med. 2008:83:52-64.

22. Angell JW, Grove-White DH, Duncan JS. Contagious ovine digital dermatitis - a questionnaire survey of 511 sheep farms in Wales. 17th International Symposium and 9th International Conference on Lameness in Ruminants, Bristol. 2013; Abstract 3,45

23. Winter JR, Kaler J, Fergusson E, Kilbride AL, Green LE. Changes in prevalence of, and risk factors for, lameness in random samples of English sheep flocks: 2004-2013. Prev Vet Med. 2015;122:121-8.

24. Groenevelt M. Small ruminant lameness-it is time to have four feet on the ground. Intern. Sheep Vet Society Congress, Harrogate 2017. Abstract.

25. Lottner S, Ganter M. Klauenkrankheiten IV: Moderhinke konsequent und erfolgreich Sanieren (in German). Deutsche Schafzucht. 2004;21:4-8.

26. Egerton JR, Roberts DS. Vaccination against ovine foot-rot. J Comp Pathol. 1971:81:179-85

27. Gradin JL, Schmitz JA. Selective medium for isolation of Bacteroides nodosus. J Clin Microbiol. 1977;6:298-302.

28. La Fontaine S, Egerton JR, Rood JI. Detection of Dichelobacter nodosus using species specific oligonucleotides as PCR primers. Vet Microbiol. 1993;35:101-17.

29. Belloy L, Giacometti M, Boujon P, Waldvogel A. Detection of Dichelobacter nodosus in wild Ungulates (Capra ibex ibex and Ovis aries musimon) and domestic sheep suffering from foot rot using a two-step polymerase chain reaction. JWildl Dis. 2007;43:82-8.

30. Moore LJ, Woodward MJ, Grogono-Thomas R. The occurrence of treponemes in contagious ovine digital dermatitis and the characterisation of associated Dichelobacter nodosus. Vet Microbiol. 2005;111:199-209.

31. Duncan JS, Angell JW, Carter S, Evans NJ, Sullivan LE, Grove-White $\mathrm{DH}$. Contagious ovine digital dermatitis: an emerging disease. Vet J. 2014;201:265-8.

32. Han GG, Lee JY, Jin GD, Park J, Choi YH, Kang SK, et al. Tracing of the fecal microbiota of commercial pigs at five growth stages from birth to shipment. Sci Rep. 2018;8:6012. https://doi.org/10.1038/s41598-01824508-7.
33. Clegg SR, Sullivan LE, Bell J, Blowey RW, Carter SD, Evans NJ. Detection and isolation of digital dermatitis treponemes from skin and tail lesions in pigs. Res Vet Sci. 2016;104:64-70.

34. Evans NJ, Timofte D, Isherwood DR, Brown JM, Williams JM, Sherlock K, et al. Host and environmental reservoirs of infection for bovine digital dermatitis treponemes. Vet Microbiol. 2012;156:102-9.

35. Sullivan LE, Blowey RW, Carter SD, Duncan JS, Grove-White DH, Page P, et al. Presence of digital dermatitis treponemes on cattle and sheep hoof trimming equipment. Vet Rec. 2014;175:201. https://doi.org/10.1136/ vr.102269.

36. Klitgaard K, Nielsen MW, Ingerslev HC, Boye M, Jensen TK. Discovery of bovine digital dermatitis associated Treponema spp. in the dairy herd environment by a targeted deep sequencing approach. Appl Environ Microbiol. 2014;80:4427-32.

37. Orgel C. Continuous assessment of lameness in dairy cows and the effect of lameness on milk yield, fertility and health condition in different dairy herds. Thesis: University of Veterinary Medicine, Hannover; 2010.

38. Wilson-Welder JH, Nally JE, Alt DP, Palmer MV, Coatney J, Plummer P. Experimental transmission of bovine digital dermatitis to sheep: development of an infection model. Vet Pathol. 2018;55:245-57.

39. Angell JW, Duncan JS, Carter SD, Grove-White DH. Farmer reported prevalence and factors associated with contagious ovine digital dermatitis in Wales: a questionnaire of 511 sheep farmers. Prev Vet Med. 2014;113:132-8.

40. Angell JW, Grove-White DH, Duncan JS. Sheep and farm level factors associated with contagious ovine digital dermatitis: a longitudinal repeated cross-sectional study of sheep on six farms. Prev Vet Med. 2015;122:107-20.

41. Whittington RJ, Nicholls PJ. Grading the lesions of ovine footrot. Res Vet Sci. 1995;58:26-34.

\section{Publisher's Note}

Springer Nature remains neutral with regard to jurisdictional claims in published maps and institutional affiliations.
Ready to submit your research? Choose BMC and benefit from:

- fast, convenient online submission

- thorough peer review by experienced researchers in your field

- rapid publication on acceptance

- support for research data, including large and complex data types

- gold Open Access which fosters wider collaboration and increased citations

- maximum visibility for your research: over 100M website views per year

At BMC, research is always in progress.

Learn more biomedcentral.com/submissions 